\section{Kinetics and products composition of catalytic hydration of ethylene oxide in the presence of layered double hydroxides}

Prof. Eleonora BUTENKO Donetsk National University - M.Sc.Chemical faculty, June 2007. Specialization: Analytical Chemistry, Donetsk, Ukraine. Pryazovskyi State Technical - Ph.D. Environmental Safety, October 2011, Protection of water bodies using synthetic anionic clays, Kharkov, Ukraine. Pryazovskyi State Technical University - Head of Department of Chemical Technology and Engineering, 2018 present, Mariupol, Ukraine.

ELEONORA BUTENKO - Azov Sea State Technical University; Ukraine - butenkoeo@rambler.ru ELENA KAPUSTINA - Environmental Protection Agency; Cincinnati, USA - kapustinalena@gmail.com ALEXEY KAPUSTIN - Miami University; Oxford, USA - kapustinlesha@gmail.com

Érkezett: 2020. 05. 19. - Received: 19. 05. 2020. - https://doi.org/10.14382/epitoanyag-jsbcm.2021.2

\section{Abstract}

The reaction of ethylene oxide hydration proceeds under acid and basic catalysis. Using of heterogeneous catalysts allows to adjust the length of the chain. The kinetics of the selective hydration of ethylene oxide in aqueous solution in the presence of layered double hydroxides as heterogeneous catalysts was studied. It was shown that the molecular weight distribution of the reaction products depends on the concentration of active sites on the catalyst surface as well as the inner structure of the catalysts.

Keywords: layered double hydroxide, ethylene oxide, catalysis, kinetics Kulcsszavak: réteges kettôs hidroxid, etilén-oxid, katalízis, kinetika

Dr. Elena KAPUSTINA Mendeleev University of Chemical Technology - M.Sc. Chemical Engineering, May 1981 Specialization: Technology of solid fuels, Moscow, Russia. Mendeleev University of Chemical Technology - Ph.D. Chemical Engineering, December 1986, Carbon technology and coal processing, Moscow, Russia. Pryazovskyi State

Technical University - Research Associate, August 1986-2014, Department of Chemical Technology and Engineering, Mariupol, Ukraine. Environmental Protection Agency, Researcher, Water Department, 2015-present, Cincinnati, USA.

Prof. Alexey KAPUSTIN

Mendeleev University of Chemical Technology - M.Sc. Chemical Engineering, May 1981, Specialization: Catalysis, Moscow, Russia. Mendeleev University of Chemical Technology Ph.D. Chemical Engineering, January1985, Catalysis, Moscow, Russia. Mendeleev University of Chemical Technology - Doctor of Science (Chemistry), December 1996, Catalysis, Moscow, Russia. Pryazovskyi State Technical University - Research Associate, September 1985-2015, Department of Chemical Technology and Engineering, Mariupol, Ukraine. Miami University - Professor, 2015-present, Oxford, USA.

Selective hydration of ethylene oxide by inorganic salt system as homogeneous catalysts was studied. The highest monoethylene glycol selectivity was obtained with $99 \%$ conversion of ethylene oxide, even at low water/ethylene oxide ration.

Thekinetics of selective hydration of ethylene and propylene oxides in concentrated aqueous solutions is studied during homogeneous catalysis by sodium bicarbonate. The mathematical model of the process with determined parameters adequately describing the rate of the reaction and products distribution is developed. [3-5].

The goal of the present work was to study the kinetics of the hydration reaction of ethylene oxide in the presence of layered double hydroxides (LDH) [6].

\section{Materials and methods}

LDHs were prepared by adding $\mathrm{Mg}\left(\mathrm{NO}_{3}\right)_{2} \cdot 6 \mathrm{H}_{2} \mathrm{O}$ and $\mathrm{Al}\left(\mathrm{NO}_{3}\right)_{3} \cdot 9 \mathrm{H}_{2} \mathrm{O}$ in de-ionized water. After complete dissolution, the above solution was added dropwise to a vigorously stirred $\mathrm{Na}_{2} \mathrm{CO}_{3}$ solution in the de-ionized water. Freshly prepared $1 \mathrm{M} \mathrm{NaOH}$ solution was then added dropwise to the above solution to maintain constant $\mathrm{pH}$ of 11 . The resultant gel was aged by stirring at $85^{\circ} \mathrm{C}$ for 24 hours. The precipitate was then separated from the solution by centrifugation, washed several times with de-ionized water and dried in vacuum. All these reactions were carried out in an inert atmosphere.

$\mathrm{X}$-ray diffraction patterns revealed that well-crystallized hydrotalcite-like compounds were obtained and no other phase was identified. The X-ray diffraction for these samples typically consist of anionic clay having molecular formula $\mathrm{Mg}_{6} \mathrm{Al}_{2}(\mathrm{OH})_{16} \mathrm{CO}_{3}$. 
Basic properties of LDHs catalysts were determined with a Hammett indicator titration method in the presence of Bromothymol Blue $\left(\mathrm{pK}_{\mathrm{a}}=7.2\right)$.

The special technique was used in order to investigate acidic and basic properties by means of titration with Hammett indicators. A sample of $\mathrm{LDH}$ and a magnetic stirrer were inserted into a small glass, which was then put on a magnetic stirring device and filled with benzene. After that, a glass cylinder divided by porous separator, with a standard sample, was inserted into the small glass.

After the Hammett indicator was added into benzene the changes in color could be seen on the surface of the standard sample.

Catalytic activity was studied in the reaction of hydration of ethylene and propylene oxide. $1 \mathrm{~g}$ of $\mathrm{LDH}$ was carried out into a $5 \mathrm{ml}$ glass ampoule under a nitrogen stream, and $10 \mathrm{ml}$ of a-oxide was introduced. The ampoule was frozen by liquid nitrogen, seal after the degassing and kept into a bath with the device for shaking. The product was washed with acetone and analyzed by chromatography.

Kinetic studies were carried out with Mg-Al-LDH formed with acetate, as the sample with the largest specific surface area. Beforehand, the catalyst was converted to its basic form.

It should be noted that the most effective catalysts for the hydration of $a$-oxides are LDH in their basic form [6-8].

\section{Results and discussion}

The activity of LDH as heterogeneous catalysts is determined by the number of basic sites, as well as their availability, which correlates with the specific surface area (Fig. 1).

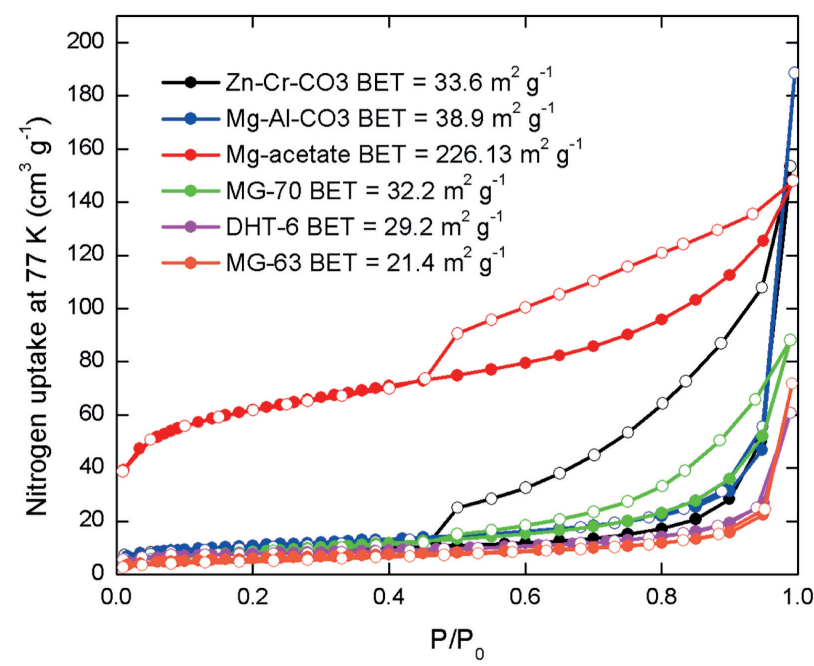

Fig. 1 Specific surface area of some LDHs

1. ábra LDH-k fajlagos felülete

The obtained kinetic data showed that at a concentration of the $\mathrm{LDH}$ basic sites of $0.5 \mathrm{~mol} / \mathrm{l}$, the distribution coefficient $\mathrm{b}=\mathrm{k}_{1} / \mathrm{k}_{0}$ decreases by 10 or more times to $0.1-0.2$. This makes it possible to obtain ethylene glycol with high selectivity at molar ratios of water-ethylene oxide close to one.

The mechanism of catalytic hydration of $\alpha$-oxide with anions is the nucleophilic addition of the catalyst anion $\left(\mathrm{A}^{-}\right)$to the a-oxide molecule:

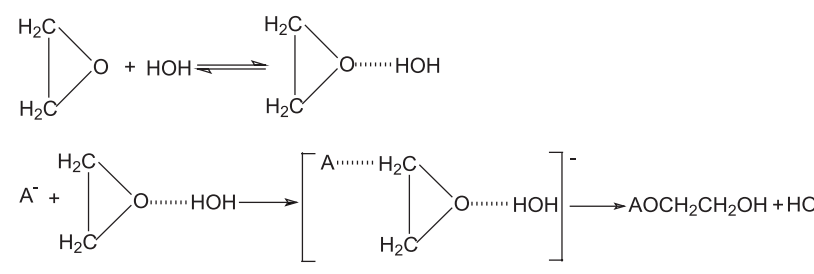

And the further hydrolysis of the intermediate ester to produce glycol and catalyst regeneration:

$\mathrm{AOCH}_{2} \mathrm{CH}_{2} \mathrm{OH}+\mathrm{HO}^{-} \longrightarrow \mathrm{A}^{-}+\mathrm{HOCH}_{2} \mathrm{CH}_{2} \mathrm{OH}$

The rate-limiting step in most cases is the stage of formation of the intermediate ester according to reaction (III). In dilute aqueous solutions the reaction rate is described by the following kinetic equation:

$\mathrm{r}=\mathrm{k}\left[\mathrm{C}_{2} \mathrm{H}_{4} \mathrm{O}\right]\left[\mathrm{A}^{-}\right]$

To implement the catalytic process of hydration of concentrated solutions of ethylene oxide, it is necessary to establish a kinetic model of reaction (3) suitable for the quantitative description of a heterogeneous catalytic process in a wide range of concentrations of water and ethylene glycol.

Our kinetic experiments showed that the immobilization of anions on heterogeneous carriers does not change the form of kinetic equation (5) and its parameters. To describe the heterogeneous catalytic reaction, it is sufficient to change the concentration of the heterogeneous catalyst $\left[\mathrm{A}^{-}\right]$in equation (5) by the number of active sites per unit volume of the reaction mass.

Such a model can be constructed taking into account the results of experiments on homogeneous catalytic hydration.

To establish such a module one can assume a trimolecular mechanism of the ring opening of the oxide cycle $(2,3)$, which is also adequate to describe the non-catalytic hydration reaction and the polyglycol formation reaction:

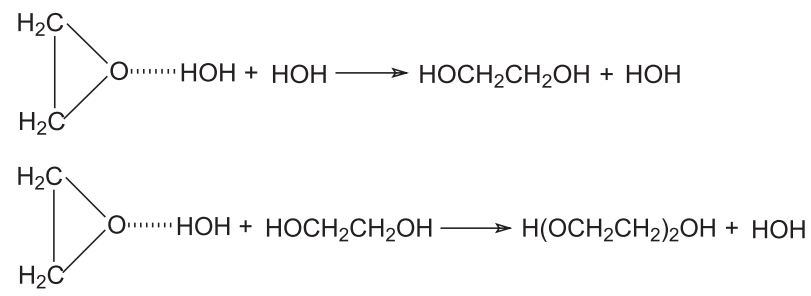

In concentrated aqueous solutions of glycols, it must be taken into account that ethylene oxide solvates in equilibrium (2) not only with water, but also with glycols. The effective concentration of proton donor substances that activate the oxide cycle due to the formation of hydrogen bond can be denoted as $[\mathrm{SH}]$ :

$[\mathrm{SH}]=\left[\mathrm{H}_{2} \mathrm{O}\right]+\mathrm{p} \Sigma\left[\mathrm{Gly}_{\mathrm{i}}\right]$

where $\Sigma\left[\mathrm{Gly}_{\mathrm{i}}\right]$ is the sum of the concentrations of ethylene glycol and all polyglycols; $\mathrm{p}$ is the parameter characterizing the efficiency of solvation of ethylene oxide.

Assuming that equilibrium (2) is quickly established and shifted to the left, equation (5) for concentrated glycol solutions takes the following form: 
$\mathrm{r}=\mathrm{k}_{\text {cat }}\left[\mathrm{A}^{-}\right]\left[\mathrm{C}_{2} \mathrm{H}_{4} \mathrm{O}\right][\mathrm{SH}]$

Taking into account that the non-catalytic reactions of ethylene oxide (1) proceeding in parallel with the mechanism $(6,7)$, we can obtain the general kinetic equation for the consumption of ethylene oxide in concentrated solutions during nucleophilic catalysis:

$-\mathrm{d}\left[\mathrm{C}_{2} \mathrm{H}_{4} \mathrm{O}\right] / \mathrm{dt}=\left(\mathrm{k}_{0}\left(\left[\mathrm{H}_{2} \mathrm{O}\right]+\mathrm{b} \Sigma\left[\mathrm{Gly}_{\mathrm{i}}\right]\right)+\mathrm{k}_{\mathrm{ct}}\left[\mathrm{A}^{-}\right]\right)$

$\left(\left[\mathrm{H}_{2} \mathrm{O}\right]+\mathrm{p} \Sigma\left[\mathrm{Gly}_{\mathrm{i}}\right]\right)\left[\mathrm{C}_{2} \mathrm{H}_{4} \mathrm{O}\right]$

In equation (10), the known equality of the rate constants of the consecutive steps of reaction (1) was taken into account, starting from the second one, i.e. $\mathrm{b}=\mathrm{k}_{1} / \mathrm{k}_{0}=\mathrm{k}_{2} / \mathrm{k}_{0}=\mathrm{k}_{3} / \mathrm{k}_{0} \ldots$

The parameters of equation (10) were determined using $\mathrm{Mg}$ $\mathrm{Al}$-acetate as a catalyst.

Initially in order to refine the distribution coefficient $b$, a series of experiments was carried out to determine the product composition of non-catalytic hydration of ethylene oxide in the range of ethylene oxide - water molar ratios $\beta$ of 0.1-0.4. The experiments were carried out in an autoclave at $90{ }^{\circ} \mathrm{C}$ until the complete conversion of ethylene oxide. The amount of mono-, di- and triethyleneglycol in the reaction products was determined via gas-liquid chromatography. The results are shown in Table 1.

\begin{tabular}{ccccccc}
$\boldsymbol{\beta}$ & \multicolumn{2}{c}{ Monoglycol, \% } & \multicolumn{2}{c}{ Diglycol, \% } & \multicolumn{2}{c}{ Triglycol, \% } \\
$\mathbf{0 . 1}$ & Exp. & Calc. & Exp. & Calc. & Exp. & Calc. \\
\hline $\mathbf{0 . 2}$ & 22.74 & 21.74 & 3.82 & 3.38 & 0.36 & 0.29 \\
\hline $\mathbf{0 . 3}$ & 31.91 & 32.63 & 10.11 & 10.87 & 1.80 & 2.04 \\
\hline $\mathbf{0 . 4}$ & 35.03 & 35.20 & 15.83 & 16.09 & 4.04 & 4.16
\end{tabular}

Table 1 The product composition of the non-catalytic hydration of ethylene oxide $(b=2.1)$ 1. táblázat Az etilén-oxid nem katalitikus hidratálásának termékösszetétele $(b=2,1)$

According to the equation (10), the rates of formation of ethylene glycol $\left(\mathrm{Gly}_{1}\right)$ and polyglycols $\left(\mathrm{Gly}_{\mathrm{i}}\right)$ in the absence of a catalyst $\left(\mathrm{k}_{\text {cat }}\left[\mathrm{A}^{-}\right]=0\right)$ is described according to the equation (11):

- d $\left[\mathrm{Gly}_{1}\right] / \mathrm{dt}=\mathrm{k}_{0}\left(\left[\mathrm{H}_{2} \mathrm{O}\right]-\mathrm{b}\left[\mathrm{Gly}_{1}\right]\right)\left(\left[\mathrm{H}_{2} \mathrm{O}\right]+\mathrm{p} \Sigma\left[\mathrm{Gly}_{\mathrm{i}}\right]\right)\left[\mathrm{C}_{2} \mathrm{H}_{4} \mathrm{O}\right]$ $-\mathrm{d}\left[\mathrm{Gly}_{\mathrm{i}}\right] / \mathrm{dt}=\mathrm{k}_{0} \mathrm{~b}\left(\left[\mathrm{Gly}_{\mathrm{i}-1}\right]-\left[\mathrm{Gly}_{\mathrm{i}}\right]\right)\left(\left[\mathrm{H}_{2} \mathrm{O}\right]+\mathrm{p} \Sigma\left[\mathrm{Gly}_{\mathrm{i}}\right]\right)\left[\mathrm{C}_{2} \mathrm{H}_{4} \mathrm{O}\right]$

Dividing equation (11) by equation (10) and taking into account that $\mathrm{k}_{\text {cat }}\left[\mathrm{A}^{-}\right]=0$, one can obtain the equations $(12,13)$ to estimate the product composition shown in Table 1:

$\mathrm{d}\left[\mathrm{Gly}_{1}\right] / \mathrm{d}\left[\mathrm{C}_{2} \mathrm{H}_{4} \mathrm{O}\right]=\left(\left[\mathrm{H}_{2} \mathrm{O}\right]-\mathrm{b}\left[\mathrm{Gly}_{1}\right]\right) /\left(\left[\mathrm{H}_{2} \mathrm{O}\right]+\right.$

$\left.\mathrm{b}\left(\left[\mathrm{H}_{2} \mathrm{O}\right]_{0}-\left[\mathrm{H}_{2} \mathrm{O}\right]\right)\right)$

$\mathrm{d}\left[\mathrm{Gly}_{\mathrm{i}}\right] / \mathrm{d}\left[\mathrm{C}_{2} \mathrm{H}_{4} \mathrm{O}\right]=\mathrm{b}\left(\left[\mathrm{Gly}_{\mathrm{i}-1}\right]-\left[\mathrm{Gly}_{\mathrm{i}}\right]\right) /\left(\left[\mathrm{H}_{2} \mathrm{O}\right]\right.$

$\left.+\mathrm{b}\left(\left[\mathrm{H}_{2} \mathrm{O}\right]_{0}-\left[\mathrm{H}_{2} \mathrm{O}\right]\right)\right)$

Processing the experimental data summarized in Table 1 using the obtained equations (12 and 13) allowed for the calculation of the value $b=2.1 \pm 0.1$ - at this value, the best agreement between the calculated and experimental values is observed.
In order to determine the remaining unknown parameters of equation (10), a series of kinetic experiments were carried out with varying concentrations of LDH catalyst, water, ethylene glycol, and temperature. The reaction rate was measured by the pressure drop of ethylene oxide vapor over the reaction mixture. The initial concentration of ethylene oxide was in the range of $0.5-1.0 \mathrm{~mol} / \mathrm{l}$ and water in a mixture of ethylene glycol-water from 20 to $80 \mathrm{wt}$. \%. The experimental conditions provided the first-order kinetics for ethylene oxide.

The experimental values of the first-order rate constant were calculated as the slope in coordinates $\ln \mathrm{P}$ vs. time, where $\mathrm{P}$ is the partial pressure of ethylene oxide.

The first-order rate constants are shown in Table. 2, calculated using the equation (14):

$$
\mathrm{K}=\left(\mathrm{k}_{0}\left(\left[\mathrm{H}_{2} \mathrm{O}\right]+\mathrm{bS}\left[\mathrm{Gly}_{\mathrm{i}}\right]\right)+\mathrm{k}_{\text {cat }}\left[\mathrm{HCO}_{3}^{-}\right]\right)\left(\left[\mathrm{H}_{2} \mathrm{O}\right]+\mathrm{pS}\left[\mathrm{Gly}_{\mathrm{i}}\right]\right)
$$

\begin{tabular}{|c|c|c|c|c|c|c|}
\hline \multirow{4}{*}{$\begin{array}{c}\mathbf{C}_{\text {cat, }} \\
\text { mol/ }\end{array}$} & \multicolumn{6}{|c|}{ Temperature } \\
\hline & \multicolumn{2}{|c|}{$70^{\circ} \mathrm{C}$} & \multicolumn{2}{|c|}{$80^{\circ} \mathrm{C}$} & \multicolumn{2}{|c|}{$90^{\circ} \mathrm{C}$} \\
\hline & $\mathbf{K}_{\text {exp. }}$ & $\mathbf{K}_{\text {calc. }}$ & $\mathbf{K}_{\text {exp. }}$ & $\mathbf{K}_{\text {calc. }}$ & $\mathbf{K}_{\text {exp. }}$ & $\mathbf{K}_{\text {calc. }}$ \\
\hline & \multicolumn{6}{|c|}{ Water } \\
\hline \multirow{4}{*}{$\begin{array}{c}0 \\
0.1 \\
0.3 \\
0.5\end{array}$} & 3.63 & 3.65 & 8.07 & 8.14 & 16.76 & 17.39 \\
\hline & 5.41 & 5.46 & 13.04 & 12.49 & 27.81 & 27.30 \\
\hline & 8.46 & 9.08 & 21.41 & 21.15 & 47.98 & 47.07 \\
\hline & 1.20 & 1.27 & 30.65 & 29.79 & 64.08 & 66.78 \\
\hline \multicolumn{7}{|c|}{ Water - $80 \%$, ethylene glycol - $20 \%$} \\
\hline \multirow{4}{*}{$\begin{array}{c}0 \\
0.1 \\
0.3 \\
0.5\end{array}$} & 3.17 & 3.34 & 7.66 & 7.46 & 15.62 & 15.94 \\
\hline & 6.03 & 5.02 & 11.71 & 11.47 & 25.74 & 25.09 \\
\hline & 8.19 & 8.36 & 19.84 & 19.48 & 45.67 & 43.35 \\
\hline & 10.20 & 11.70 & 25.54 & 27.46 & 60.60 & 61.55 \\
\hline \multicolumn{7}{|c|}{ Water - $60 \%$, ethylene glycol - $40 \%$} \\
\hline \multirow{4}{*}{$\begin{array}{c}0 \\
0.1 \\
0.3 \\
0.5\end{array}$} & 2.84 & 3.03 & 6.62 & 6.77 & 13.43 & 14.45 \\
\hline & 4.38 & 4.56 & 10.75 & 10.44 & 22.50 & 22.82 \\
\hline & 7.13 & 7.62 & 19.41 & 17.75 & 49.93 & 39.52 \\
\hline & 9.59 & 10.67 & 25.99 & 25.05 & 55.71 & 56.16 \\
\hline \multicolumn{7}{|c|}{ Water - $40 \%$, ethylene glycol - $60 \%$} \\
\hline \multirow{4}{*}{$\begin{array}{c}0 \\
0.1 \\
0.3 \\
0.5\end{array}$} & 2.47 & 2.71 & 5.54 & 6.06 & 10.79 & 12.93 \\
\hline & 4.29 & 4.10 & 9.31 & 9.37 & 19.66 & 20.49 \\
\hline & 6.60 & 6.86 & 16.17 & 15.97 & 33.32 & 35.56 \\
\hline & 8.91 & 9.61 & 23.41 & 22.56 & 45.23 & 50.58 \\
\hline \multicolumn{7}{|c|}{ Water - $20 \%$, ethylene glycol - $80 \%$} \\
\hline \multirow{4}{*}{$\begin{array}{c}0 \\
0.1 \\
0.3 \\
0.5\end{array}$} & 1.92 & 2.39 & 4.33 & 5.33 & 8.16 & 11.38 \\
\hline & 3.59 & 3.62 & 8.86 & 8.27 & 19.02 & 18.09 \\
\hline & 6.26 & 6.07 & 15.02 & 14.13 & 33.16 & 31.47 \\
\hline & 7.98 & 8.51 & 21.85 & 20.00 & 45.19 & 44.80 \\
\hline
\end{tabular}

Table 2 The rate constants of the hydration of ethylene oxide, $s^{-1} ; 10^{5}$ 2. táblázat Az etilén-oxid hidratálásának sebességi állandói, $\mathrm{s}^{-1} ; 10^{5}$

The calculation of the parameters of equation (14), which provide an adequate description of the experimental data, results in the following values of $\mathrm{k}_{0}=\exp (9.1-9355 / \mathrm{T}), \mathrm{l}^{2} /$ $\left(\mathrm{mol}^{2} \mathrm{~s}\right) ; \mathrm{k}_{\mathrm{cat}}=\exp (18.2-10574 / \mathrm{T}), \mathrm{l}^{2} /\left(\mathrm{mol}^{2} \cdot \mathrm{s}\right) ; \mathrm{p}=1.88$.

The good agreement between the calculated and experimental values in Table 3 confirms the sufficiency of the obtained model for describing the reaction rate and selectivity of the catalytic hydration of ethylene oxide and the possibility of its use in the development of an industrial process. 


\begin{tabular}{|c|c|c|c|c|}
\hline$\beta$ & $\begin{array}{l}{[\text { Gly }]} \\
\text { mol/L, } \\
\text { exp. }\end{array}$ & $\begin{array}{l}{\left[\mathrm{Gly}_{1}\right] \text {, }} \\
\mathrm{mol} / \mathrm{L} \text {, } \\
\text { calc. } \\
{ }^{\circ} \mathrm{C}, \mathrm{C}_{\text {cat }}\end{array}$ & $\begin{array}{l}\text { Reaction } \\
\text { yield, \%, } \\
\text { exp. } \\
\text { mol/L }\end{array}$ & $\begin{array}{c}\text { Reaction } \\
\text { yield, \%, } \\
\text { calc. }\end{array}$ \\
\hline 0.062 & 2.88 & 2.79 & 94.9 & 91.9 \\
\hline 0.082 & 3.52 & 3.47 & 91.0 & 89.7 \\
\hline 0.101 & 4.19 & 4.04 & 91.1 & 87.8 \\
\hline 0.124 & 4.77 & 4.66 & 87.9 & 85.9 \\
\hline \multicolumn{5}{|c|}{$\mathrm{T}=95^{\circ} \mathrm{C}, \mathrm{C}_{\text {cat }}=0.2 \mathrm{~mol} / \mathrm{L}$} \\
\hline 0.039 & 1.94 & 1.90 & 97.1 & 95.1 \\
\hline 0.072 & 3.15 & 3.11 & 91.1 & 89.9 \\
\hline 0.098 & 3.98 & 3.92 & 88.7 & 87.3 \\
\hline 0.131 & 4.8 & 4.75 & 84.8 & 83.9 \\
\hline 0.178 & 5.72 & 5.72 & 80.3 & 80.3 \\
\hline 0.220 & 6.32 & 6.38 & 76.5 & 77.2 \\
\hline
\end{tabular}

Table 3 Experimental and calculated concentrations and reaction yields of ethylene glycol at various molar ratios of ethylene oxide-water (b)

3. táblázat Kísérleti és számított etilén-glikol koncentrációk és reakció-hozamok az etilén-oxid-víz különböző mólarányainál

\section{Conclusions}

LDHs are effective catalysts for industrial organic synthesis.

The activity of $\mathrm{LDH}$ is determined by the number of basic active sites on the surface, which, in turn, depends on the structure and chemical composition.

The use of LDHs as heterogeneous catalysts allows to move from homogeneous to heterogeneous catalysis, which reduces the environmental pollution effect.

\section{References}

[1] Tapio Salmi Ethylene oxide - kinetics and mechanism. Current Opinion in Chemical Engineering, 2012, V. 1-3, p. 321-327. https://doi.org/10.1016/j.coche.2012.06.002

[2] Georges, A. M. - Arturo, G. - Marc, E. L.: Kinetics of the reactions of ethylene oxide with water and ethylene glycols. Process Safety Progress, 2001, V. 20, p. 231-246. https://doi.org/10.1002/prs.680200405

[3] Butenko, E. - Kapustin, A. - Dan, O.: Propylene oxide polymerization in the presence of layered double hydroxides. Chemistry-Didactics-EcologyMetrology, 2018, V. 23, N. 1-2, p. 137-142. https://doi.org/10.1515/cdem-2018-0009

[4] Butenko, E. - Kapustin, A.: Catalysis by Pillared Layered Double Hydroxides. Biomedical Journal of Scientific \& Technical Research (BJSTR). 2019, V. 22, N1, p. 16289-16290 https://doi.org/10.26717/bjstr.2019.22.003681

[5] Butenko, E. - Kapustin, A.: Mercarbide Catalyst for Alcohol Ethoxylation. Journal of Siberian Federal University. Chemistry, 2020, V. 13, № 3, p 330-339. https://doi.org/10.17516/1998-2836-0186

[6] Penaloza, David P.: Modified clay for the synthesis of clay-based nanocomposites. Epitoanyag, 2019, V. 71, N 1, p. 5-11. https://doi.org/10.14382/epitoanyag-jsbcm.2019.2

[7] Butenko, E.: Sorption reseaches on the removal of the bond ammonia from the wastewater. Epitoanyag, 2019, V. 71, N 3, p. 84-86. https://doi.org/10.14382/epitoanyag-jsbcm.2019.15

[8] Jinchang, Z. - Tiechun, L.: Facile synthesis of a highly effective layered double hydroxide catalyst and its application in the one-step ethoxylation of butyl acetate to oligo-ethylene glycol butyl ether acetates. Ind. Eng. Chem. Res. 2019, V. 58, p. 16320-16325. https://doi.org/10.1021/acs.iecr.9b01892

$\underline{\text { Ref.: }}$

Butenko, Eleonora - Kapustina, Elena - Kapustin, Alexey: Kinetics and products composition of catalytic hydration of ethylene oxide in the presence of layered double hydroxides Építőanyag - Journal of Silicate Based and Composite Materials, Vol. 73, No. 1 (2021), 9-12. p. https://doi.org/10.14382/epitoanyag-jsbcm.2021.2

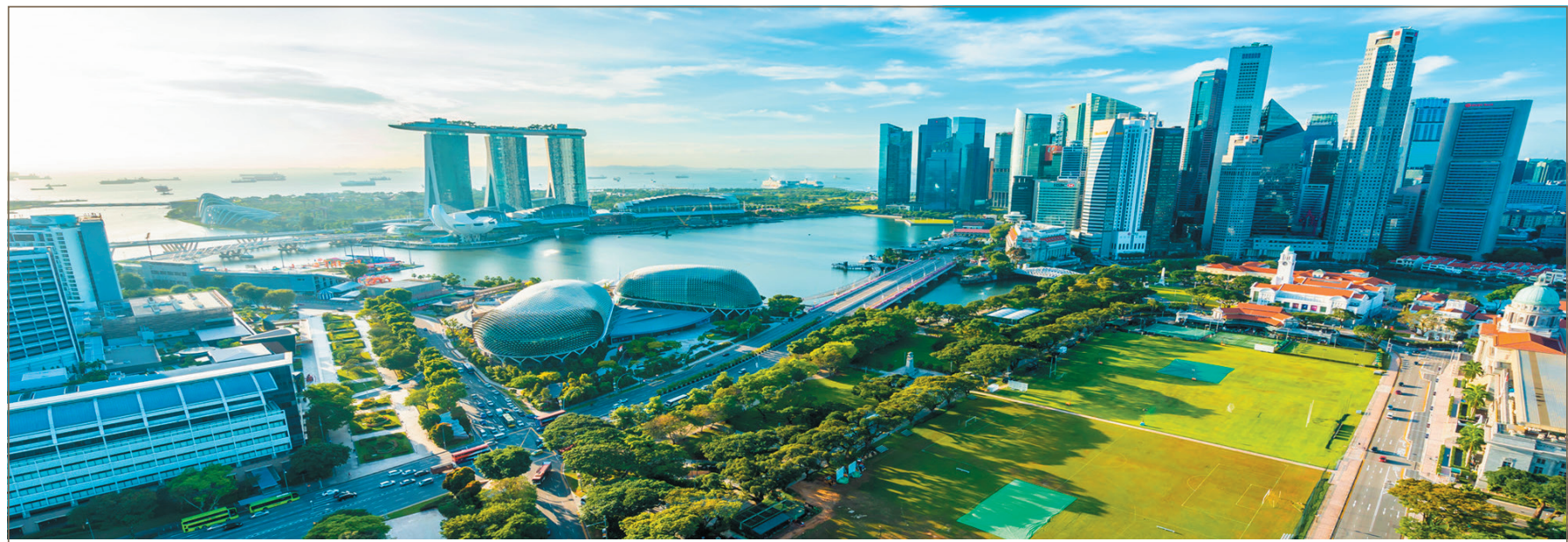

\section{ICCEN 2021}

$20219^{\text {th }}$ International Conference on Civil Engineering will be held during October 14-16, 2021 in Singapore.

ICCEN 2021 is co-sponsored by the Hong Kong Chemical, Biological \& Environmental Engineering Society (HKCBEES). It is one of the leading international conferences for presenting novel and fundamental advances in the fields of Civil Engineering. It also serves to foster communication among researchers and practitioners working in a wide variety of scientific areas with a common interest in improving Civil Engineering related techniques. 